\title{
Genetic and other factors determining mannose-binding lectin levels in American Indians: the Strong Heart Study
} Lyle G Best*1, Robert E Ferrell2, Susan DeCroo ${ }^{2}$, Kari E North ${ }^{3}$, Jean W MacCluer ${ }^{4}$, Ying Zhang ${ }^{5}$, Elisa T Lee ${ }^{5}$, Barbara V Howard ${ }^{6}$, Jason Umans ${ }^{6}$, Vittorio Palmieri ${ }^{7}$ and Peter Garred ${ }^{8}$

\author{
Address: ${ }^{1}$ Missouri Breaks Industries Research Inc, Timber Lake, SD, USA, ${ }^{2}$ University of Pittsburgh, Pittsburgh, PA, USA, ${ }^{3}$ University of North \\ Carolina, Chapel Hill, NC, USA, ${ }^{4}$ Southwest Foundation for Biomedical Research, San Antonio, TX, USA, ${ }^{5}$ University of Oklahoma Health Sciences \\ Center, Oklahoma City, OK, USA, ${ }^{6}$ Medstar Research Institute, Washington, DC, USA, ${ }^{7}$ Cornell Medical Center, New York, NY, USA and \\ ${ }^{8}$ Rigshositalet, University of Copenhagen, Copenhagen, Denmark \\ Email: Lyle G Best* - sbest@utma.com; Robert E Ferrell - robert.ferrell@mail.hgen.pitt.edu; Susan DeCroo - susan.decroo@mail.hgen.pitt.edu; \\ Kari E North - kari_north@unc.edu; Jean W MacCluer - jean@sfbrgenetics.org; Ying Zhang - Ying-Zhang4@ouhsc.edu; Elisa T Lee - elisa- \\ lee@ouhsc.edu; Barbara V Howard - barbara.v.howard@medstar.net; Jason Umans - jason.umans@gmail.com; \\ Vittorio Palmieri - vpalmier@med.cornell.edu; Peter Garred - garred@post5.tele.dk \\ * Corresponding author
}

Published: 22 January 2009

BMC Medical Genetics 2009, 10:5 doi:10.1186/147I-2350-10-5

This article is available from: http://www.biomedcentral.com/I47/-2350// 0/5

(c) 2009 Best et al; licensee BioMed Central Ltd.

This is an Open Access article distributed under the terms of the Creative Commons Attribution License (http://creativecommons.org/licenses/by/2.0), which permits unrestricted use, distribution, and reproduction in any medium, provided the original work is properly cited.
Received: 3 July 2008

Accepted: 22 January 2009

\begin{abstract}
Background: Mannose-binding lectin (MBL) forms an integral part of the innate immune system. Persistent, subclinical infections and chronic inflammatory states are hypothesized to contribute to the pathogenesis of atherosclerosis. MBL gene (MBL2) variants with between 12 to $25 \%$ allele frequency in Caucasian and other populations, result in markedly reduced expression of functional protein. Prospective epidemiologic studies, including a nested, case-control study from the present population, have demonstrated the ability of MBL2 genotypes to predict complications of atherosclerosis,. The genetic control of MBL2 expression is complex and genetic background effects in specific populations are largely unknown.
\end{abstract}

Methods: The Strong Heart Study is a longitudinal, cohort study of cardiovascular disease among American Indians. A subset of individuals genotyped for the above mentioned case-control study were selected for analysis of circulating MBL levels by double sandwich ELISA method. Mean MBL levels were compared between genotypic groups and multivariate regression was used to determine other independent factors influencing MBL2 expression.

Results: Our results confirm the effects of variant structural (B, C, and $D)$ and promoter $(H$ and $Y$ ) alleles that have been seen in other populations. In addition, MBL levels were found to be positively associated with male gender and hemoglobin Alc levels, but inversely related to triglyceride levels. Correlation was not found between MBL and other markers of inflammation.

Conclusion: New data is presented concerning the effects of known genetic variants on MBL levels in an American Indian population, as well as the relationship of MBL2 expression to clinical and environmental factors, including inflammatory markers. 


\section{Background}

Early innate human defenses against microbial invaders include mannose-binding lectin (MBL), a serum protein, which acts as a microbial opsonin and initiates activation of the so-called lectin complement activation pathway. Deficiencies in innate immunity have been hypothesized to allow chronic inflammatory states that may contribute to the pathogenesis of atherosclerosis [1]. Common variations in the MBL gene (MBL2), between 12 to $25 \%$ allele frequencies in Caucasian and other populations [2], result in markedly lower levels of circulating MBL [3] and are associated with both an increased susceptibility to infections [4] and cardiovascular disease in many [5-8], but not all studies [9]. An independent association between variant MBL2 genotypes and coronary artery disease (CAD) was previously confirmed in the American Indian, Strong Heart Study (SHS) cohort $(\mathrm{OR}=3.2,95 \%$ CI 1.5-7.0, $\mathrm{p}=$ 0.004 , adjusted for 11 CAD covariates) [10]. On the other hand, genetypes resulting in high levels of MBL may be involved in complications related to cardiovascular disease (CVD). Thus, the role of MBL in cardiovascular disease appears to be a double-edged sword, due to hitherto only partially resolved mechanisms [11-13].

Although considerable effort has focused on the genotypic determination of MBL levels, our understanding of the role of various promoters and structural genetic variations remains incomplete. New promoter variants continue to be identified $[14,15]$ and genetic background effects in specific populations are largely unknown.

MBL is also known to increase during an acute-phase reaction [16]. Samples collected during follow-up of a subset of the SHS cohort provide a valuable opportunity to test the correlation of both genotype and environmental exposures (e.g. incident CAD and inflammation, as measured by C-reactive protein (CRP) or fibrinogen) with MBL levels in this population.

\section{Methods}

The previously mentioned SHS case/control study matched cases and controls on age, gender and recruitment center (Arizona (AZ), Dakotas (DK) and Oklahoma $(\mathrm{OK}))$. From this group a subset was chosen to include 186 of the controls without regard to genotype and an additional 51 cases limited to those known to be homozygous for high expressing "HYA" alleles.

Ascertainment of fatal and nonfatal cardiovascular events occurring between examinations was accomplished by medical record review and/or yearly participant contact [17]. Cases were defined by evidence of definite myocardial infarction (MI), definite coronary artery disease (CAD) without MI, definite evidence of MI by Minnesota ECG coding [17], or mortality codes indicating either def- inite $\mathrm{MI}$, sudden death due to $\mathrm{CAD}$, or definite coronary heart disease occurring between 5/18/89 and 12/31/99 [18]. Participants with only a diagnosis of possible CAD, "other CAD", stroke, congestive heart failure, or peripheral vascular disease were excluded. Controls were those individuals without any of the above diagnoses. MBL levels, MBL2 genotypes and other covariates were determined from both of these groups. American Diabetes Association criteria [19] were used to classify participant diabetic status in table 1. Participants were considered hypertensive if they were taking anti-hypertensive medications, had a systolic blood pressure greater than $140 \mathrm{~mm}$ $\mathrm{Hg}$, or a diastolic blood pressure greater than $90 \mathrm{~mm} \mathrm{Hg}$.

Determination of MBL levels was done at Rigshositalet in Copenhagen, Denmark, using a double sandwich ELISA method as previously described [20].

The MBL2 gene was assessed for the presence of the $\mathrm{B}$ (G54D), C (G57E) or D (R52C) structural variations, and two promoter polymorphisms, one a $\mathrm{G} / \mathrm{C}$ transition at 550 bp (the $\mathrm{H} / \mathrm{L}$ alleles) [21] and the other, a G/C transition at -221 (X/Y alleles). These structural variations have typically been labeled " $\mathrm{O}$ " alleles in contrast to the most common "A" allele. Genotypes were determined by the oligonucleotide ligation assay as described by Nickerson and colleagues [22]. Quality control, duplicate, genotyping was performed by direct DNA sequencing. The structural variations were assumed to occur on opposing chromosomes. A number of promoter variants and structural alleles have been found to be in complete linkage disequilibrium and genotypes were checked against these established relationships. [23]. Genotyping was conducted at the University of Pittsburgh, Pittsburgh, Pennsylvania.

Composite categories of genotypes predicted to result in reduced expression of $M B L 2$ similar to previous reports [3], primarily A_A, A_O, O_O, YA_O, XA_O, HA_O, LA_O, HYA_O, LYA_O, LXA_O, along with selected specific haplotypes of adequate prevalence, were used to guide analysis of genotypic effects on MBL levels. More inclusive categories used in the previous SHS MBL2 analysis [10] were also considered. Low expression of MBL2 (LOW_1) was assumed from the presence of an $\mathrm{O} \_\mathrm{O}$ or LA_O genotype. The LOW_2 category consisted of either O_O, LA_O or LA_LA genotypes. These risk categories were compared with reference groups ALL_1 or ALL_2, consisting of all genotypes not included in either LOW_1 or LOW_2 respectively; or the HIGH category (either HA_HA or HA_LA). There is ample documentation of the biologic effect of these various genotypes on basal MBL levels [23], although unidentified background genetic influences in unique populations are of interest. 
Table I: Characteristics of cases and controls analyzed.

\begin{tabular}{|c|c|c|}
\hline Characteristic & $\begin{array}{l}\text { Cases } \\
N=51\end{array}$ & $\begin{array}{l}\text { Controls } \\
N=186\end{array}$ \\
\hline Gender (\% Female) & 49 & 52 \\
\hline Age (years) & 60.1 & 58.7 \\
\hline Percentage of participants reporting $100 \% \mathrm{Al}$ heritage & 78 & 68 \\
\hline Median percent $\mathrm{Al}$ heritage among those with less than $100 \%$ & 65.6 & 50 \\
\hline Diabetes Mellitus (\%) & 64.7 & 39.8 \\
\hline Hypertension (\%) & 27.5 & 22.6 \\
\hline Smoking, current (\%) & 37.3 & 25.3 \\
\hline Alcohol, current use (\%) & 41 & 36 \\
\hline Weight (Kg) & 82.9 & 84.2 \\
\hline BMI $\left(\mathrm{Kg} / \mathrm{m}^{2}\right)$ & 29.4 & 30.4 \\
\hline $\mathrm{Hgb}$ Alc (\%) & 8.2 & 6.4 \\
\hline LDL Cholesterol (mg/dl) & 130.2 & 119.1 \\
\hline Triglycerides (mg/dl) & 198.1 & 125.5 \\
\hline CRP (mg/dl) & 2.99 & 3.45 \\
\hline Fibrinogen (mg/dl) & 319.8 & 304.7 \\
\hline PAl-I (mg/dl) & 43.3 & 46.8 \\
\hline
\end{tabular}

The Chi square statistic was used to evaluate proportions between groups. Multivariate regression models and comparison of means ( $\mathrm{t}$ test of independent samples) were used to understand the contribution of the various factors to MBL2 expression using SPSS version 10.1.0 software. The distributions of all subgroups in table 2 were examined and no deviation from the normal distribution was detected. A nominal p value of 0.05 was used to determine statistical significance and the Bonferroni correction was applied in situations of multiple testing.

Approval consistent with the Helsinki Declaration was obtained from all relevant Institutional Review Boards and tribes, and all participants gave informed consent.

\section{Results}

Table 1 summarizes the characteristics of both cases and controls. Please note that cases for this study were chosen on the basis of genotype and since cases and controls were initially matched for gender, age, and recruitment center, comparison between aggregated case and control samples should be interpreted with caution.

There were no significant differences in the prevalence of $\mathrm{O}(15.3 \%)$ and $\mathrm{H}(67.2 \%)$ alleles in this control sample, compared with an earlier SHS report [10].

These findings confirm low levels of MBL among individuals with composite genotypic groups (eg O_O, XA_O, LA_O) [2], as well as those previously associated with CAD in this SHS population (bolded) [10], as seen in table 2 .

Among controls only, comparing means of composite genotypes showed highly significant differences $(\mathrm{p}<$ 0.001 for all comparisons) between either the HYA_HYA or HIGH groups and any of the YA_O, HA_O, LA_O, O_O, LOW1, or LOW2 groups. Figure 1 shows these comparisons in the familiar "box-plot" format. The difference in mean MBL between HYA_HYA and HYA_LYA (unad- 
Table 2: MBL levels $(\mu \mathrm{g} / \mathrm{L})$ found in various genotypes and genotypic categories.

\begin{tabular}{|c|c|c|c|c|c|}
\hline Haplotype & $N$ & Min & Max & Mean & SD \\
\hline \multicolumn{6}{|l|}{ Controls } \\
\hline HYA_HYA & 76 & 128 & 3920 & 1863.2 & 854.95 \\
\hline HYA_LYA & 34 & 400 & 3296 & 1422.6 & 826.14 \\
\hline HYA_LXA & 21 & 223 & 2848 & 1030.8 & 709.6 \\
\hline LYA_LYA & 2 & 1040 & 3024 & 2032.0 & 1402.9 \\
\hline LYA_LXA & I & & & 1376.0 & \\
\hline LXA_LXA & I & & & 3616.0 & \\
\hline HYA_B & 27 & 0 & 768 & 168.9 & 150.7 \\
\hline HYA_C & I & & & 273.0 & \\
\hline HYA_D & 7 & 157 & 1840 & 696.29 & 585.9 \\
\hline LYA_B & 8 & 24 & 233 & 115.25 & 84.1 \\
\hline LYA_D & 1 & & & 448.0 & \\
\hline LXA_B & I & & & 0.0 & \\
\hline B_B & 6 & 0 & 0 & 0.0 & \\
\hline YA_O & 44 & 0 & 1840 & 251.7 & 321.9 \\
\hline XA_O & I & & & 0.0 & \\
\hline XA_O or O_O & 7 & 0 & 0 & 0.0 & \\
\hline HA_HA & 76 & 128 & 3920 & 1863.2 & 854.9 \\
\hline HA_LA & 55 & 223 & 3296 & 1273.0 & 800.3 \\
\hline LA_LA & 4 & 1040 & 3616 & 2264.0 & 1250.6 \\
\hline HA_O & 35 & 0 & 1840 & 277.3 & 351.3 \\
\hline LA_O & 10 & 0 & 448 & 137.0 & 137.0 \\
\hline $\mathrm{HIGH}$ & $13 \mid$ & 128 & 3920 & 1615.4 & 879.3 \\
\hline LOW_I & 16 & 0 & 448 & 85.6 & 126.3 \\
\hline LOW_2 & 20 & 0 & 3616 & 521.3 & 1029.0 \\
\hline A_A & 135 & 128 & 3920 & 1634.7 & 893.0 \\
\hline Not "A_A" & 51 & 0 & 1840 & 217.2 & 311.1 \\
\hline \multicolumn{6}{|l|}{ Cases } \\
\hline HYA_HYA & 51 & 640 & 5888 & 1903.6 & 1043.4 \\
\hline
\end{tabular}

justed for multiple testing, $\mathrm{p}<0.013$ ), was not significant considering a Bonferroni correction requiring a p < 0.00365 for a total of 14 pair-wise tests. No significant differences were found between MBL means of HYA_LYA and HYA_LXA or HYA_B and LYA_B (although the last category was represented by only 8 individuals); other comparisons attempting to isolate the influence of the $\mathrm{H} /$ $\mathrm{L}$ or $\mathrm{X} / \mathrm{Y}$ promoters were not possible due to small numbers of individuals in categories.

Only cases with HYA_HYA genotype were included to allow adequate numbers to compare with controls of identical genotype. If the mean MBL levels for case and control groups of identical genotype are compared (ignoring the previously matched selection of cases and controls on the basis of age, gender and center), then a crude $\mathrm{p}$ value of 0.812 is obtained.

Multivariate regression analysis was used to investigate the interplay of various demographic, environmental, genetic factors on expression of $M B L 2$ within the control group. A backward selection criterion of $\mathrm{F} \geq 0.1$ was used and results are summarized in table 3. Male gender, hemoglobin A1c levels and self-reported \% American Indian ethnicity are positively correlated with MBL levels; whereas the converse is true of increasing triglyceride levels and the number of $B$ alleles. Covariates not retained in this backward selection included: age, diabetes mellitus, systolic blood pressure, Chlamydia pneumoniae (Cp) antibody titers, percent body fat, and urinary albumin/ creatinine ratio. Although MBL is an acute phase reactant, it was not correlated with either inflammatory measures (CRP, PAI-1, fibrinogen, WBC count) or infectious disease exposure (Cp titers).

\section{Discussion}

Genetic variation in the MBL2 gene has been implicated in important pathophysiologic processes including susceptibility to infections [24-26], chronic inflammatory states and their sequelae $[5,6,8,27]$, and the response to acute pathology, such as ischemic necrosis [28]. Further down the pathogenetic chain of events, circulating levels of this protein are also associated with pathology $[27,29,30]$. It is therefore important to fully understand the genetic and environmental factors governing expression of this protein. Since MBL is a polymeric protein comprised of self-assembled trimeric subunits, dominantnegative structural variants were first recognized to have marked effects on functional MBL levels. Promoter polymorphisms were soon recognized as key determinants of MBL2 expression and as recently as 2006, new variants have been identified $[3,15,31]$. It is likely that additional influences (eg the endocrine milleu [32,33], variation in multimeric assembly [34], and epigenetic effects determined by the "background" population [3] on MBL2 


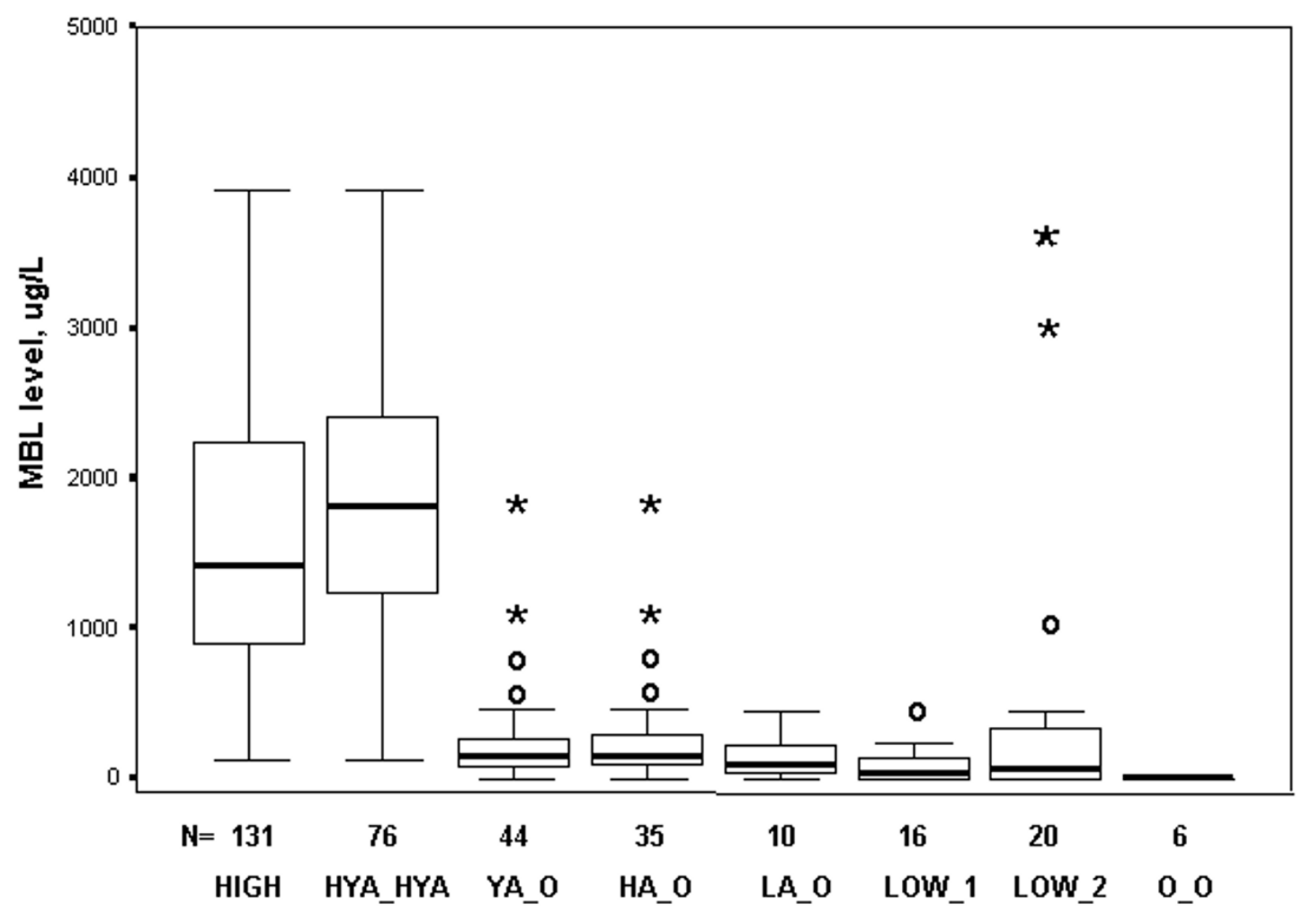

Figure I

MBL levels for various genotypes. Comparison of mean HIGH and HYA_HYA MBL levels with all other groups is significant at $p<0.00 \mathrm{I}$. Outliers (between I.5 and 3 box lengths from upper and lower margin) and extreme values (greater than 3 box lengths from box margin) are denoted by "o" and "*" respectively.

expression and function will continue to be uncovered. The worldwide high population prevalence of these variants suggests an apparently ambivalent role of MBL2 in a number of pathogenetic and homeostatic processes [3537].

In this report we have generally confirmed the previously reported influence of the three main structural variants and the two most widely investigated promoter variants $(\mathrm{H} / \mathrm{L}$ and $\mathrm{X} / \mathrm{Y})$. This is of importance due to the demonstrated association between CVD and these variants in this particular, non-Caucasian population. Other studies have reported on the prevalence of $M B L 2$ variants in native populations of North America [38]; but have not included information on the expression of $M B L 2$, as in the present study. Since MBL levels are higher in those with diabetes (although not seen in this dataset) [27], a correlation with
HgbA1c could be expected. The finding of an association with lower levels of triglycerides in adjusted analysis is more difficult to explain, especially since triglyceride levels are often increased in those with diabetes or the metabolic syndrome [39]. Others have also reported increased MBL levels among males [30]; but no previous analyses of triglycerides in relation to MBL could be found in the literature.

Strengths of this study include confirmation of the presumed link between genotype and expressed protein, increasing confidence in a possibly causal association between MBL and cardiovascular disease in this population. These results also extend the previously identified genotype/phenotype correlations to another population with a unique genetic background. A weakness is the previous matching structure of the sample and the need to 
Table 3: Results of multivariate regression analysis on the control group $(n=186)$.

\begin{tabular}{lll}
\hline Factor & beta coefficient & P value \\
\hline MALE GENDER & .161 & .011 \\
\hline \% AMERICAN INDIAN ETHNICITY & .216 & .001 \\
\hline In TRIGLYCERIDES & -.159 & .013 \\
\hline HEMOGLOBIN AIc & .219 & .001 \\
\hline
\end{tabular}

compare HYA/HYA case genotypes with the same control genotypes. There were an insufficient number of previously matched pairs with this genotype to allow a matched analysis, thus the aggregate comparison between these two groups needs to be interpreted with caution.

\section{Conclusion}

The findings from our study corroborate previous research that has demonstrated the important effects of genetic variants and the association of metabolic abberations with MBL levels. Further understanding of MBL2 expression may improve our ability to understand and disrupt the pathogenetic mechanisms involved in cardiovascular disease.

\section{Competing interests}

The authors declare that they have no competing interests.

\section{Authors' contributions}

All authors have read and approved the final manuscript. LB: Originated and conducted the majority of the analysis, drafted the manuscript and is the corresponding author. $\mathrm{RF}$ and SD: Supervised and conducted the genotyping. KN, JM, EL, BH, JU and VP: Provided recommendations on analysis and assisted in editing the manuscript. YZ: Provided provided critical statistical supplort and validation. PG: Supervised laboratory determination of MBL levels, as well as providing major contributions in developing the analytic strategy and key editorial recommendations.

\section{Acknowledgements}

This work was supported by cooperative agreement grants U0I-HL65520, UOI-HL4I642, UOI-HL4I652, UOI-HL4I654, and UOI-HL6552I from the National Heart, Lung and Blood Institute, Bethesda, MD. We thank the SHS participants, Indian Health Service facilities, and participating tribal communities for their extraordinary cooperation and involvement, which has contributed to the success of the Strong Heart Study. The work of Ms Vibeke Weirup in analysis of MBL levels and the support of the Novo Nordisk foundation, the Danish Medical Research Council, and the Rigsphospitalet of Copenhagen are greatly appreciated. The views expressed in this paper are those of the authors and do not necessarily reflect those of the Indian Health Service.

\section{References}

I. Hansson GK, Robertson AK, Söderberg-Nauclér C: Inflammation and atherosclerosis. Annu Rev Pathol 2006, I:297-329.

2. Garred P, Larsen F, Seyfarth J, Fujita R, Madsen HO: Mannose-binding lectin and its genetic variants. Genes Immun 2006, 7:85-94.

3. Garred P, Larsen F, Madsen HO, Koch C: Mannose-binding lectin deficiency-revisited. Mol Immunol 2003, 40:73-84.

4. Dommett RM, Klein N, Turner MW: Mannose-binding lectin in innate immunity: past, present and future. Tissue Antigens 2006, 68:193-209.

5. Madsen HO, Videm V, Svejgaard A, Svennevig JL, Garred P: Association of mannose-binding-lectin deficiency with severe atherosclerosis. Lancet 1998, 352:959-60.

6. Rugonfalvi-Kiss S, Endrész V, Madsen HO, Burián K, Duba J, Prohászka Z, Karádi I, Romics L, Gönczöl E, Füst G, Garred P: Association of Chlamydia pneumoniae with coronary artery disease and its progression is dependent on the modifying effect of mannose-binding lectin. Circulation 2002, 106:107I-6.

7. Calvo-Alén J, Alarcón GS, Tew MB, Tan FK, McGwin G Jr, Fessler BJ, Vilá LM, Reveille JD, LUMINA Study Group: Systemic lupus erythematosus in a multiethnic US cohort: XXXIV. Deficient mannose-binding lectin exon I polymorphisms are associated with cerebrovascular but not with other arterial thrombotic events. Arthritis Rheum 2006, 54:1940-5.

8. Hegele RA, Ban MR, Anderson CM, Spence JD: Infection-susceptibility alleles of mannose-binding lectin are associated with increased carotid plaque area. J Investig Med 2000, 48: 198-202.

9. Albert MA, Rifai N, Ridker PM: Plasma levels of cystatin-C and mannose binding protein are not associated with risk of developing systemic atherosclerosis. Vasc Med 200I, 6: I45-9.

10. Best LG, Davidson M, North KE, MacCluer JW, Zhang Y, Lee ET, Howard BV, DeCroo S, Ferrell RE: Prospective analysis of mannose-binding lectin genotypes and coronary artery disease in American Indians: the Strong Heart Study. Circulation 2004, 1 09:47|-5.

II. Rugonfalvi-Kiss S, Dosa E, Madsen HO, Endresz V, Prohaszka Z, Laki J, Karadi I, Gonczol E, Selmeci L, Romics L, Fust G, Entz L, Garred P: High rate of early restenosis after carotid eversion endarterectomy in homozygous carriers of the normal mannosebinding lectin genotype. Stroke 2005, 36:944-8.

12. Hansen TK, Gall MA, Tarnow L, Thiel S, Stehouwer CD, Schalkwijk CG, Parving $\mathrm{HH}$, Flyvbjerg A: Mannose-binding lectin and mortality in type 2 diabetes. Arch Intern Med 2006, I 66:2007-I 3.

13. Troelsen LN, Garred P, Madsen HO, Jacobsen S: Genetically determined high serum levels of mannose-binding lectin and agalactosyl IgG are associated with ischemic heart disease in rheumatoid arthritis. Arthritis Rheum 2007, 56:21-9.

14. Bernig T, Taylor JG, Foster CB, Staats B, Yeager M, Chanock SJ: Sequence analysis of the mannose-binding lectin (MBL2) gene reveals a high degree of heterozygosity with evidence of selection. Genes Immun 2004, 5:46I-76.

15. Boldt AB, Luty A, Grobusch MP, Dietz K, Dzeing A, Kombila M, Kremsner PG, Kun JF: Association of a new mannose-binding lectin variant with severe malaria in Gabonese children. Genes Immun 2006, 7:393-400.

16. Thiel S, Holmskov U, Hviid L, Laursen SB, Jensenius JC: The concentration of the C-type lectin, mannan-binding protein, in human plasma increases during an acute phase response. Clin Exp Immunol 1992, 90:3 I-5.

17. Howard BV, Lee ET, Cowan LD, Fabsitz RR, Howard WJ, Oopik AJ, Robbins DC, Savage PJ, Yeh JL, Welty TK: Coronary heart disease prevalence and its relation to risk factors in American Indians. The Strong Heart Study. Am J Epidemiol I 995, I 42:254-68.

18. Lee ET, Welty TK, Fabsitz R, Cowan LD, Le NA, Oopik AJ, Cucchiara AJ, Savage PJ, Howard BV: The Strong Heart Study. A study of cardiovascular disease in American Indians:design and methods. Am J Epidemiol 1990, I32: | |4|-55.

19. Report of the Expert Committee on the Diagnosis and Classification of Diabetes Mellitus. Diabetes Care 1997, 20(7): I 182-I 197.

20. Garred P, Madsen HO, Kurtzhals JA, Lamm LU, Thiel S, Hey AS, Svejgaard A: Diallelic polymorphism may explain variations of the blood concentration of mannan-binding protein in Eskimos, but not in black Africans. Eur J Immunogenet 1992, 19:403-12.

21. Garred P, Thiel S, Madsen HO, Ryder LP, Jensenius JC, Svejgaard A: Gene frequency and partial protein characterization of an 
allelic variant of mannan binding protein associated with low serum concentrations. Clin Exp Immunol 1992, 90:517-2I.

22. Nickerson DA, Kaiser R, Lappin S, Stewart J, Hood L, Landegren U: Automated DNA diagnostics using an ELISA-based oligonucleotide ligation assay. Proc Natl Acad Sci USA 1990, 87:8923-7.

23. Madsen HO, Garred P, Thiel S, Kurtzhals JA, Lamm LU, Ryder LP, Svejgaard A: Interplay between promoter and structural gene variants control basal serum level of mannan-binding protein. J Immunol 1995, I 55:30 |3-20.

24. Koch A, Melbye M, Sørensen P, Homøe P, Madsen HO, Mølbak K, Hansen $\mathrm{CH}$, Andersen LH, Hahn GW, Garred P: Acute respiratory tract infections and mannose-binding lectin insufficiency during early childhood. JAMA 200I, 285:|3|6-2I.

25. Roy S, Knox K, Segal S, Griffiths D, Moore CE, Welsh KI, Smarason A, Day NP, McPheat WL, Crook DW, Hill AV, Oxford Pneumoccocal Surveillance Group: MBL genotype and risk of invasive pneumococcal disease: a case-control study. Lancet 2002, 359:1569-73.

26. Summerfield JA, Sumiya M, Levin M, Turner MW: Association of mutations in mannose binding protein gene with childhood infection in consecutive hospital series. BMJ 1997, 3 | 4: 1229-32.

27. Hansen TK, Tarnow L, Thiel S, Steffensen R, Stehouwer CD, Schalkwijk CG, Parving HH, Flyvbjerg A: Association between mannose-binding lectin and vascular complications in type I diabetes. Diabetes 2004, 53:1570-6.

28. Jordan JE, Montalto MC, Stahl GL: Inhibition of mannose-binding lectin reduces postischemic myocardial reperfusion injury. Circulation 2001, 104:1413-8.

29. Kielgast S, Thiel S, Henriksen TB, Bjerke T, Olsen J, Jensenius JC: Umbilical cord mannan-binding lectin and infections in early childhood. Scand J Immunol 2003, 57:167-72.

30. Saevarsdottir S, Oskarsson OO, Aspelund T, Eiriksdottir G, Vikingsdottir T, Gudnason V, Valdimarsson H: Mannan binding lectin as an adjunct to risk assessment for myocardial infarction in individuals with enhanced risk. J Exp Med 2005, 20I: I I7-25.

31. Jüliger S, Kremsner PG, Alpers MP, Reeder JC, Kun JF: Restricted polymorphisms of the mannose-binding lectin gene in a population of Papua New Guinea. Mutat Res 2002, 505:87-9I.

32. Hansen TK, Thiel S, Dall R, Rosenfalck AM, Trainer P, Flyvbjerg A, Jørgensen JO, Christiansen JS: GH strongly affects serum concentrations of mannan-binding lectin: evidence for a new IGF-I independent immunomodulatory effect of GH. J Clin Endocrinol Metab 200I, 86:5383-8.

33. Riis AL, Hansen TK, Thiel S, Gravholt CH, Gjedde S, Gormsen LC, Jørgensen JO, Weeke J, Møller N: Thyroid hormone increases mannan-binding lectin levels. Eur J Endocrinol 2005, 1 53:643-9.

34. Wallis R: Interactions between mannose-binding lectin and MASPs during complement activation by the lectin pathway. Immunobiology 2007, 21 2:289-99.

35. Garred P, Harboe M, Oettinger T, Koch C, Svejgaard A: Dual role of mannan-binding protein in infections: another case of heterosis? Eur J Immunogenet 1994, 21:|25-31.

36. Ezekowitz RA: Genetic heterogeneity of mannose-binding proteins: the Jekyll and Hyde of innate immunity? Am J Hum Genet 1998, 62:6-9.

37. Saevarsdottir S, Vikingsdottir T, Valdimarsson H: The potential role of mannan-binding lectin in the clearance of self-components including immune complexes. Scand I Immunol 2004, 60:23-9.

38. Hegele RA, Busch CP, Young TK, Connelly PW, Cao H: Mannosebinding lectin gene variation and cardiovascular disease in Canadian Inuit. Clin Chem 1999, 45: 1283-5.

39. Grundy SM, National Cholesterol Education Program (NCEP)-The National Cholesterol Guidelines in Adult Treatment Panel (ATP) III: Approach to lipoprotein management in $200 \mathrm{I}$ National Cholesterol Guidelines. Am J Cardiol 2002, 90: I li-2 Ii.

\section{Pre-publication history}

The pre-publication history for this paper can be accessed here:

http://www.biomedcentral.com/1471-2350/10/5/prepub
Publish with Bio Med Central and every scientist can read your work free of charge

"BioMed Central will be the most significant development for disseminating the results of biomedical research in our lifetime. "

Sir Paul Nurse, Cancer Research UK

Your research papers will be:

- available free of charge to the entire biomedical community

- peer reviewed and published immediately upon acceptance

- cited in PubMed and archived on PubMed Central

- yours - you keep the copyright 